\title{
SCREENING FOR BIOLOGICALS TO CONTROL RUMEX LUNARIA L. IN LANZAROTE ISLAND
}

\author{
María Bernardos ${ }^{1}$, Natalia Sierra Cornejo ${ }^{1}$, Carmen G. Rodríguez ${ }^{2}$, José R. Arévalo ${ }^{1}$, \\ Raimundo Cabrera ${ }^{1}$ \\ ${ }^{1}$ CIPEV Group, Department of Botany, Ecology and Plant Physiology, Biology Section, \\ Faculty of Science, Universidad de La Laguna, Tenerife, Spain \\ ${ }^{2}$ Gabinete de Estudios Ambientales (GEA), S.L.U., Tenerife, Spain. 38591 \\ Correspondence address: \\ Universidad de La Laguna, P.O. box. 456, La Laguna, \\ Tenerife, Spain, 38200 \\ e-mail: mariabernardoshernandez@gmail.com
}

http://www.doi.org/10.54574/RJPP.14.15

\begin{abstract}
Rumex lunaria L., a Polygonaceae shrub, has colonized large areas of Lanzarote, Canary Islands, from the 1980s to the present day, revealing an invasive behaviour. Recently, symptoms of disease like leaf spots and lack of turgidity in trunks have been observed. This fact has led to the investigation on fungal communities present in this invasive species in several areas of the National Park and other locations in Lanzarote Island. Our objectives were to detect and select fungal strains with phytopathogenic traits isolated from disease symptomatic plants using different screening techniques. To isolate the potential fungi causing disease symptoms, samples were processed using mycological classical techniques. Identification of fungi was based on morphological and molecular analysis using the accepted DNA barcode for fungi, the rDNA ITS region. Five rapid and cost-effective screening methods were carried out in the laboratory in a sequential order before scaling the study to the nursery plants assay. This sequence of methods allows us to test the potential pathogenic effects of a high number of strains in a relatively short period of time: method 1 -both sides of the midrib of a cut leaf were inoculated with droplets of a spores suspension; method 2 -a branch with leaves maintained in water was inoculated with droplets of a spores suspension; method 3 -the aerial part of seedlings was sprayed with spores suspension; method 4 and 5 -leaves of an adult plant were inoculated with droplets of a spores suspension. Several scales for symptoms were developed according to strains-specific effects on tissue like chlorosis, spots and necrosis. Size of leaves spots were recorded. Of 76 fungal isolated strains, 21 genera were identified, with Alternaria and Penicillium being the most frequent. The screening process led to the selection of Alternaria tenuissima (strain 739) as it showed a constant pathogenic ability along the screening sequence. Thus, it makes it a strong potential biological control agent for the invasive species R. lunaria in Lanzarote Island. This study also contributes to the knowledge on the fungal communities of R. lunaria.
\end{abstract}

Key words: invasive plant, phytopathogenic fungi, biological control, sub-desert environment.

\section{INTRODUCTION}

Biodiversity loss is one of the most serious problems facing nature conservation (García, 2010). Invasive species are a threaten to biodiversity and one of the main environmental problems worldwide, often considered the second most important (Arévalo et al., 2015; Dueñas et al., 2021). The introduction of invasive alien species can lead to various consequences on the biological diversity of native ecosystems. Although the spread of these species is very rapid in continental ecosystems (e.g. France, UK, Romania) (Grigorescu et al., 2020), the problem of biological invasions rises in island ecosystems. The more isolated they are, the more vulnerable. Islands are rich reservoirs of biological diversity, but they are also environmentally fragile and economically vulnerable (Capdevila Argüelles, 2006). In the Canary Islands, among vascular plants, there are 2,091 species cited, of which 701 are introduced $(33.5 \%)$ and 82 are invasive introduced (3.9\%) (Arechavaleta Hernández et al., 2010). 
The Canary Islands, like other islands in the world, are hotspots of biodiversity. One of the major aims of the Canarian environmental government is the conservation of the precious and fragile natural heritage present in the archipelago (Anteproyecto de Ley de biodiversidad y de los recursos naturales de Canarias, 1 de diciembre de 2021). Island ecosystems often contain many empty ecological niches due, in part, to the difficulty organisms face while trying to establish in them. This characteristic contributes to the susceptibility of ecosystems to invasion by introduced species and the extinction of endemic species (Vilà et al, 2008).

In Lanzarote Island, the nature of landscapes is mainly defined by the "fragile" substratum at high risk of colonization by invasive species. This is the case of Rumex lunaria, a translocated native plant species, which in the last eighty years has spread over a large part of the island, being nowadays one of the priority conservation targets. $R$. lunaria is a shrub belonging to the Polygonaceae family and endemic to the western islands of the Canary archipelago. Following the information of the inhabitants of the Island, it was introduced in the north of the island of Lanzarote because of its forage value in the 1930s. In the 1980s, the first plant individuals were observed in the Timanfaya National Park (Wildpret et al. 1995). Since then, the species has widely colonised the Timanfaya National Park triggering different processes, for instance, acceleration of ecological succession in the area, formation of soil and the facilitation of the colonisation by other invasive species. All these changes result on a strong alteration of the fragile and unique volcanic landscape of this island.

In its native range, it is distributed from 50 to $1200 \mathrm{~m}$ a.s.l. It has been associated with the basal floor, characterised by the dominance of species adapted to dryness and salinity. It can reach marginal areas of the Monteverde and pine forest, forming nitrophilous frutescent communities on slopes and freshly disturbed, moist, stony soils. (Gobierno de Canarias, 2011).

In Lanzarote, $R$. lunaria grows on recent volcanic soils with abundant lapilli (Coats \& Rumpho, 2014; Del Arco Aguilar et al., 2019). It is adapted to drought conditions and soils with neutral to slightly alkaline $\mathrm{pH}$, and diverse edaphic and climatic conditions (Méndez \& Álvarez, 2014). The ability to establish in this wide range of environmental conditions enhances its invasive capacity. However, various symptoms (e.g. spots on leaves and stems, loss of turgidity, malformed roots) that have been observed in plants from Lanzarote determined us to search for potential phytopathogens, on the affected plants. Since 2016, two management strategies have been developed to control this non-native plant in the National Park: mechanical and chemical techniques. Results have been partially successful (Paredes Gil et al., 2018) but they required a continuous action. Our aim was to search for potential phytopathogens, relying on the bioecological characteristics of the target species. The study consisted in selecting costeffective screening methods packed in a sequence of assays which allow to detect phytopathogenic traits of a series of diverse fungal strains.

\section{MATERIALS AND METHODS}

\section{Study area}

Lanzarote is an eastern island of the Canary archipelago $\left(29^{\circ} 14^{\prime} 05^{\prime \prime}\right.$ and $28^{\circ} 50^{\prime} 12^{\prime \prime}$ north latitude, $13^{\circ} 53^{\prime} 06^{\prime \prime}$ and $13^{\circ} 24^{\prime} 40^{\prime \prime}$ west longitude). The average annual temperature and rainfall on the island are $21^{\circ} \mathrm{C}$ and $111 \mathrm{~mm}$, respectively (AEMET, 1981-2010). According to the Köppen-Geiger climate classification, Lanzarote has a warm desert climate (BWh) (Agencia Estatal de Meteorología ,España \& Instituto de Meteorología, Portugal, 2012).

In one of the sampling areas in the north of the island, $R$. lunaria occupies areas of crops and succession shrub (Chenoleoideo tomentosae - Salsoletum vermiculatae variant with Launaea arborescens). The rest of the sampling areas are in Timanfaya National Park and Los 
Volcanes Natural Park, where the species is found on a community of rupicolous or lichenic vegetation of recent malpais (Stereocauletum vesuviani), where other shrubs such as Launaea arborescens, Polycarpaea robusta and some annual grasses occur (Del Arco Aguilar et al., 2019).

Recent volcanic substrates (Timanfaya eruption of 1730-1736) coexist with older volcanic ones (14 Ma) on the island, which are covered by dispersal pyroclasts. Most of the $R$. lunaria samples collected are found in the more recent substrates, on e.g. aa-type lava flows, cordate lava flows and lapilli.

\section{Plant Samples Collection}

Along the years, samples of affected plants were collected in Timanfaya National Park (Altos de Timanfaya, Chinero) and surrounding areas (El Golfo, Tremesana, Mazo, Yaiza and Máguez) (Figure 1). Plant organs (i.e. leaves, branches and roots) were separated in the field, placed in zip-bags and subsequently stored at $4-5{ }^{\circ} \mathrm{C}$ until further use. Samples were processed within 48 hrs.

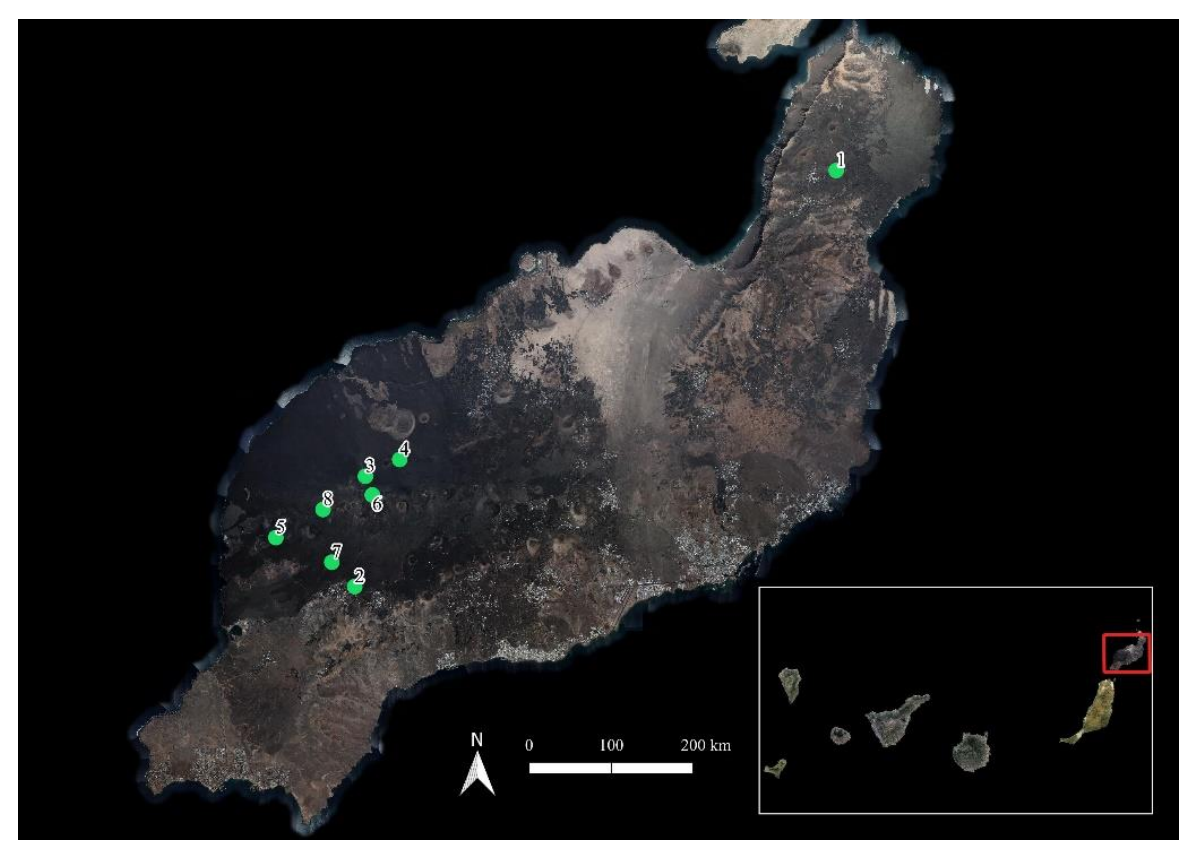

Figure 1. Sampling locations on Lanzarote Island. 1. Máguez; 2. Yaiza; 3. Chinero; 4. Mazo; 5. El Golfo; 6. Altos de Timanfaya; 7. Tremesana; 8. Montaña Rajada.

\section{Isolation of fungal strains}

To isolate the potential fungi causing disease symptoms in $R$. lunaria, samples were processed using mycological classical techniques. Fragments with symptoms of different plant organs (leaves, branches and roots) were excised and thoroughly rinsed in sterile distilled water for 1 minute. The plant material was dried on pieces of sterile filter paper under a laminar flow chamber and separated into fragments of approximately $2 \mathrm{~cm}$. Fragments were placed in potato glucose agar (PGA) plates with tetracycline $\left(10 \mathrm{mg} \mathrm{L}^{-1}\right)$ and incubated at $25^{\circ} \mathrm{C}$ in the darkness. Incubation time until purification of each strain was different according to strain velocity (2-5 days). All fungal colonies growing from the infected samples were subcultured onto PGA. As samples were collected at different times, the number of isolates varied over time. Strains were maintained for short-and long-time conservation in mineral oil at $4-5{ }^{\circ} \mathrm{C}$ and $20 \%$ glycerol at $22{ }^{\circ} \mathrm{C}$, respectively. 


\section{Fungal strain identification}

Prior to taxonomic identification, a preliminary classification was made to avoid the selection of identical strains arising from the same plant individual, separating isolates into morphotypes according to Cosoveanu et al., (2018). Briefly, we observed the shape and colour of fungal colony and characteristics of reproductive organs under microscope. Selected strains were processed for DNA extraction, amplification, and sequencing by SEGAI (General Research Support Services of the University of La Laguna). Molecular identification of the fungal strains was performed using ITS1 (5'-TCCGTAGGTGAACCTGCGG-3') and ITS4 (5'TCCTCCGCTTATTGATATGC-3') primer pair to amplify the 5.8S rDNA and the two internal transcribed spacers ITS1 and ITS2 (White et al., 1990). The sequences were run through the BLASTN search page using Megablast program (National Center for Biotechnology Information; Bethesda MD, USA) where the most identical hits (> 98\% for species and $>95 \%$ for genus) were obtained.

\section{Fungal Inoculum preparation}

PGA plates were inoculated with mycelium plugs of the fungal strains described above. After 7 -14 days of growth, depending on the growth rate of each strain, spores were washed off with distilled water, gently scraping the surface. Spores' suspensions $\left(1 \times 10^{5}\right.$ spores $\left.\mathrm{ml}^{-1}\right)$ were prepared and immediately used.

\section{Pathogenicity screening workflow}

These methods were carried out along a time sequence, covering a range of resource requirements and natural conditions: from less resources and high number of strains to high logistics and less strains. That is, from low need of material and inoculation carried out on detached organs (leaf and branch assays) to a higher logistic requirement and inoculation in more natural conditions (adult plants assay in nursery).

We tested five methods to select fungal strains with pathogenic ability on $R$. lunaria (Figure 2). Mainly, in each screening the successful strains (i.e. showing symptoms) observed before were selected, adding as new strains, the ones isolated at that time (i.e. plants were sampled in field at different times, so fungal strains were introduced in the screening process accordingly). Assays were performed on detached leaves, detached branches and entire plants (seedlings and adults).

Detached leaf assay Method 1-Healthy leaves of $R$. lunaria were tested with 32 fungal strains. Leaves were detached from a plant individual located in the garden of the Faculty of Biology at the University of La Laguna (Tenerife). Five replicates (leaves) per strain and control were used (165 leaves in total). Each leaf was placed in a $9 \mathrm{~cm}$ Petri dish and its petiole was inserted in a $1.5 \mathrm{ml}$ microtube containing moisture cotton wool. Both sides of the midrib at the adaxial leaf surface were inoculated with a droplet of $10 \mu 1$ of spore solution each ( $20 \mu 1$ in total per leaf). For the controls, the same amount of distilled water was applied.

Detached branch assay Method 2- Apical branches were cut with at least five healthy leaves from an individual plant of $R$. lunaria located in the same site as above. This method was used to test 46 strains: 19 strains selected by method 1 and 27 new isolates. Five replicates (branches) were used per strain and control (235 branches in total). Each branch was placed in a centrifuge tube with $50 \mathrm{ml}$ deionized sterile water. Five leaves per branch were inoculated as previously described.

Plant assays Method 3- Healthy $R$. lunaria seedlings were maintained in a versatile environmental test chamber under controlled conditions. We tested 31 strains: 12 strains selected by method 2 and 19 new isolates. Five replicates (seedlings) were used per strain and control (160 seedlings in total). The adaxial surface of all the leaves was sprayed with spore 
suspension until run-off point was reached. The same procedure was applied to the control seedlings but with distilled water.

Method 4- We used adult plants grown in pots to test the 10 strains selected by method 3. Plants were maintained in a chamber under controlled conditions. Five replicates (individuals) were used per strain and control (55 individuals in total). Five leaves of each adult plant were inoculated as in the methods 1 and 2, at both sides of the midrib at the adaxial leaf surface with $10 \mu \mathrm{l}$ of spore solution, in total $20 \mu \mathrm{l}$ per leaf. For the controls, the same amount of distilled water was applied.

Method 5- To select one of the three successful strains tested in all previous methods (1-4), we carried out an experiment with adult plants under greenhouse conditions. Five replicates were used per strain and control (20 adult plants in total) and five leaves per individual were inoculated following the procedure in methods 1, 2 and 4.

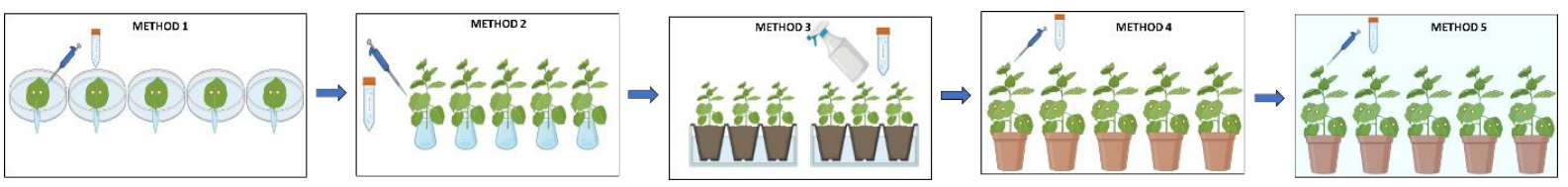

Figure 2. Experimental design of the 5 screening methods for pathogenic strains isolated from Rumex lunaria plants on Lanzarote Island.

\section{Assays conditions}

The first four screenings were carried out in a chamber in the installations of the CIPEV group at the University of La Laguna under controlled conditions with a photoperiod of 12 hours of light at a constant temperature of $21^{\circ} \mathrm{C}$. Watering was carried out twice a week. The selection criterion to determine the pathogenic ability of a strain was based on the presence of leaf spots at the end of the assay (after seven or nine days of inoculation). The plant organs screened by methods 1 and 2 were monitored daily as the leaves and branches were only viable for one week, while by methods 3 and 4 were monitored at 3, 6 and 9 days after application of the spore solution. The fifth screening method was carried out in a nursery at the Central Campus of the University of La Laguna at an average temperature of $25 \pm 9.5^{\circ} \mathrm{C}$ and an average relative humidity of $65 \pm 24.3 \%$. Watering was done three times a week. The level of pathogenicity of a strain was determined by a scale of leaf spot size where 1 - spot diameter $\leq$ $0.5 \mathrm{~cm}, 2$ - spot diameter between 0.5 and $1 \mathrm{~cm}$ and 3 - spot diameter $\geq 1 \mathrm{~cm}$. The evaluation was done at 3, 6 and 9 days after application of the spore's solution, the same procedure as in the other plant assays ( 3 and 4 ). For all methods the study design was completely randomized. We used a universal substrate containing a balanced mix of peat, perlite, agrosil and complete compost.

\section{Statistical analysis}

To determine the effect of fungal strains in method 5 on leaf spot size (represented as a scale from 0 to 3 ) of $R$. lunaria, a generalized linear mixed model with a Poisson distribution was used. We established the leaf spot size as response variable, treatment and time as fixed factors (without interaction) and individual as random factor. Analysis was carried out with the 'Imer' function of the 'lme4' package (Bates et al., 2015). Subsequently, to determine differences among groups, we carried out a Tukey's HSD post-hoc adjustment for multiple comparisons with the 'emmeans' function (Lenth, 2021). All analyses were set to a significance level of $\mathrm{p}<0.05$ and were performed using R software v.4.0.3 (R Core Team, 2020). 


\section{RESULTS AND DISCUSSIONS}

\section{Isolates identification}

A total of 76 strains belonging to 21 genera were isolated from leaves, stems and roots from affected individuals of $R$. lunaria in Lanzarote Island. We were able to identify 52 species level while 24 strains remained at genus level. Alternaria and Penicillium represent the most frequent genera, followed by Stemphylium and Aspergillus (Figure 3).

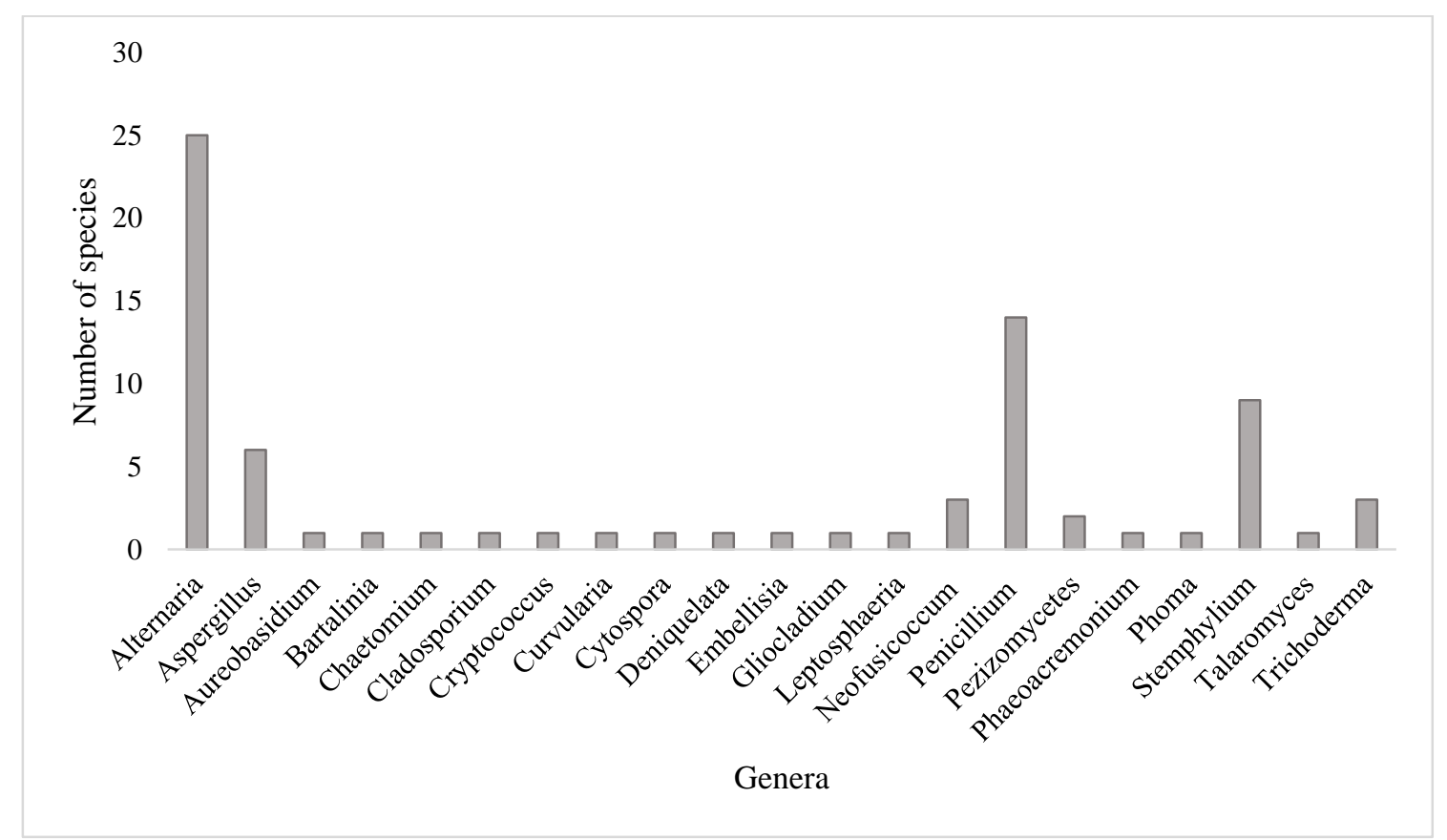

Figure 3. Number of strains per genus isolated from infected plants of $R$. lunaria in Lanzarote Island

Studies of fungal species as facultative pathogens on Rumex spp. or invasive plants are scarce and focused mainly on endophytic species (Wearn et al., 2012) and mycorrhizae (Bunn et al., 2015). Regarding invasive plants, the studies are mainly focused on the interaction between soil microbial communities and non-native plants with impact on plant fitness and adaptability (Coats \& Rumpho, 2014), shifts effect of microbiome (Malacrinò et al., 2020) or phyllosphere, air and soil mycobiome (Fang et al., 2019). Yet, fungal communities receive attention when phytopathogens (Chen et al., 2020) or facultative pathogens (Sopena et al., in prep.) are targeted. Still, most studies are mainly focused on one species-targeted like Uromyces rumicis on Rumex crispus (Inman, 1971), Alternaria alternata on Xanthium strumarium (Abdessemed et al., 2020) and Fusarium oxysporum on Opuntia ficus-indica (Pacanoski, 2015).

\section{A cost \& time-effective sequence of screening methods}

Instead of using a single method, four rapid and cost-effective screening methods were carried out in the laboratory in a sequential order before scaling the study to the nursery plants assay (method 5). This sequence of methods allows us to test the potential pathogenic effects of a high number of strains in a relatively short period of time. Starting with low requirements of resources (plant material, spore solution, space and time) and high number of strains to a higher requirement of these components but lower strains capacity testing (Figure 4). The workflow was designed to increase the natural conditions and allow the plant defence to enter into the game - from detached leaves and branches to seedlings and adult plants. Although there are known important differences in plant defence responses between detached and whole intact 
plants (Liu et al., 2007), antimicrobial activity was shown in detached leaves (Orłowska et al., 2013).

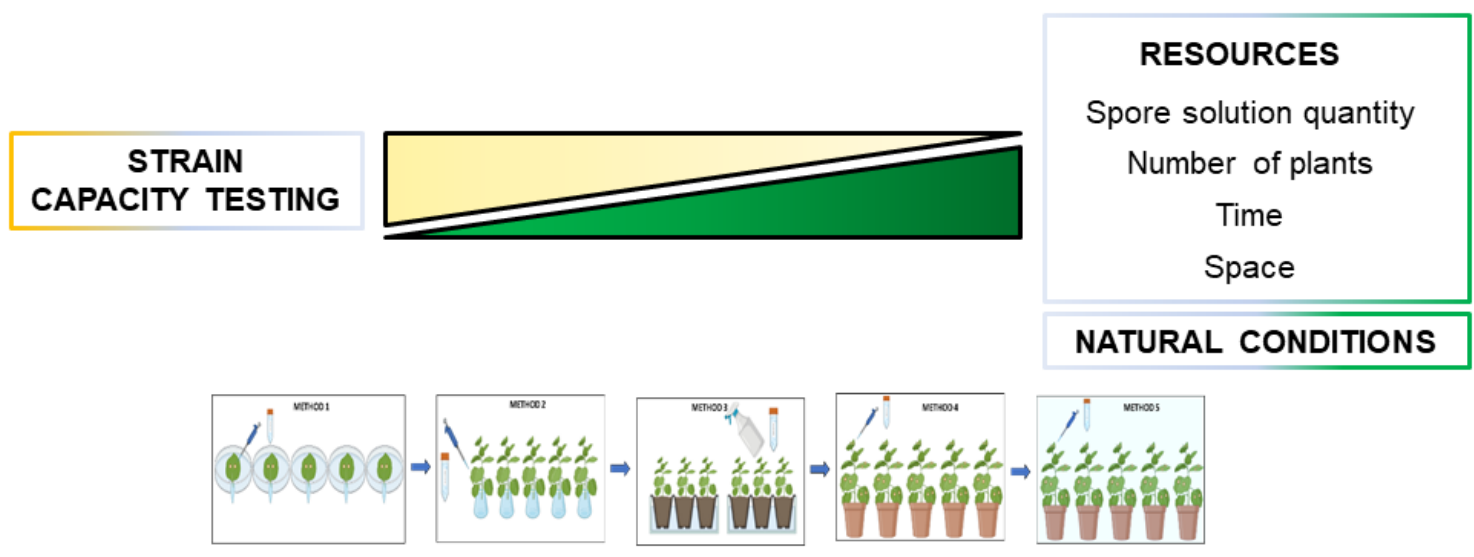

Figure 4. Sequence of methods within a cost \& time - effective approach for the search of a biological control agent.

Another two strong features of this sequence of methods are (i) the increasing robustness of the results as the number of leaves inoculated per strain increase along the screening sequence, and (ii) the use of droplets for inoculation (except for method 3), reducing the volume of spore solution needed in comparison to fumigation, and concentrating the spores in one single spot, facilitating the monitoring of the effects.

The methods proposed here are common methods used in plant pathology studies (Cirulli et al., 2008; Pratt, 1996). Their combined use enhances a rapid screening of a high number of potential biocontrol agents. Other methods consist of applying the spore solution with a brush, placing leaves on agar medium or inoculating cotyledons (Garg et al., 2008; Ren et al., 2015). Lesions are made to facilitate saprophytes or facultative pathogens to become opportunists, or to easier make observations on colonization of potential pathogens.

\section{Phytopathogenic features of the tested fungal strains}

In the first screening (detached leaves), of the 32 tested strains (17 species), 19 produced symptoms seven days after inoculation (Figure 5). In the second screening (detached branches), of 46 tested strains ( 27 species), 12 showed leaf spots after one week. In the third screening (seedlings), of 31 strains (19 species), 10 strains were successfully pathogenic after nine days. Finally, in the fourth screening (adult plants) 10 strains were tested (6 species), from which 3 gave positive results nine days after inoculation. Some of the symptoms are shown in Figure 6.

Along the different screenings, strains from the species complex Alternaria sect. Alternaria were the most frequent in showing pathogenic ability (Figure 5). 
Method 1

\begin{tabular}{|c|c|}
\hline 7 & Alternaria alternata \\
\hline \multirow[t]{2}{*}{1} & Alternaria infectoria \\
\hline & Alternaria solani \\
\hline 3 & Alternaria sp. \\
\hline 2 & Alternaria tenuissima \\
\hline \multirow[t]{4}{*}{1} & Aspergillus sp \\
\hline & Curvularia eragrostidis \\
\hline & Embellisia annulata \\
\hline & Leptosphaeria sp. \\
\hline \multirow[t]{2}{*}{1} & Neofusicoccum luteum \\
\hline & Penicillium fagi \\
\hline 1 & Stemphylium eturmiunum \\
\hline \multirow[t]{2}{*}{1} & Stemphylium simmonsii \\
\hline & Stemphylium vesicarium \\
\hline 1 & Strain 761 \\
\hline 1 & Strain 767 \\
\hline & Talaromyces pinophilus \\
\hline
\end{tabular}

\section{Method 3}

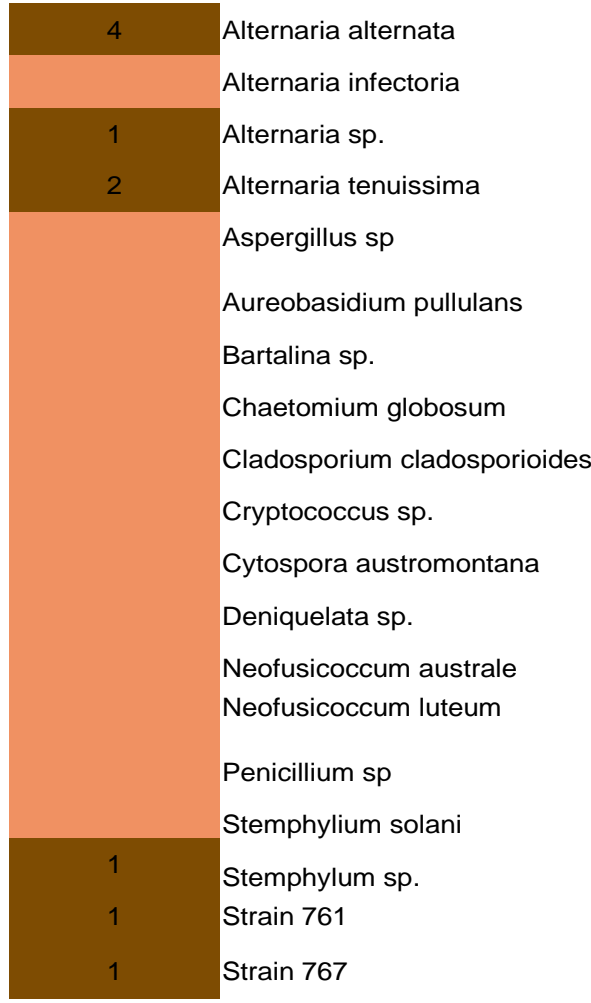

\section{Method 2}

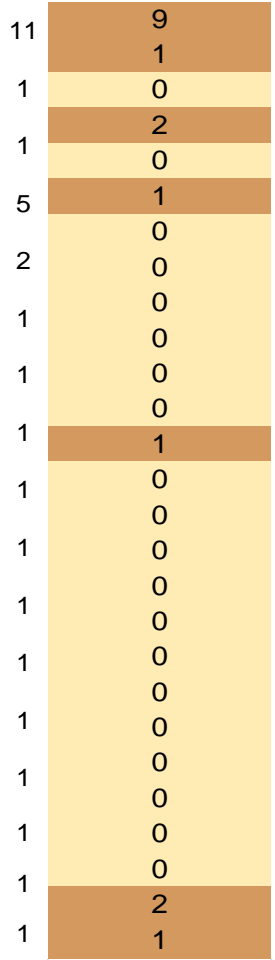

Alternaria alternata 4 Alternaria infectoria $\quad 1$ Alternaria sp. 3 Alternaria tenuissima 2 Aspergillus aculeatus $\quad 1$ Aspergillus sp Aspergillus terreus 1 Aspergillus versicolor 2 Aspergillus westerdijkiae 1 Curvularia eragrostidis $\quad 1$ Embellisia annulata Gliocladium cibotii 1 Neofusicoccum luteum 2 Penicillium amphipolaria $\quad 1$ Penicillium antarcticum 1 Penicillium canescens 1 Penicillium chrysogenum 2 Penicillium glabrum 2 Penicillium sp. 3 Penicillium thomii 1 Pezizomycetes sp. 2 Phaeoacremonium parasiticum 1 Phoma sp. Stemphylium simmonsii Stemphylium eturmiunum Strain 761 Strain 767

\section{Method 4}

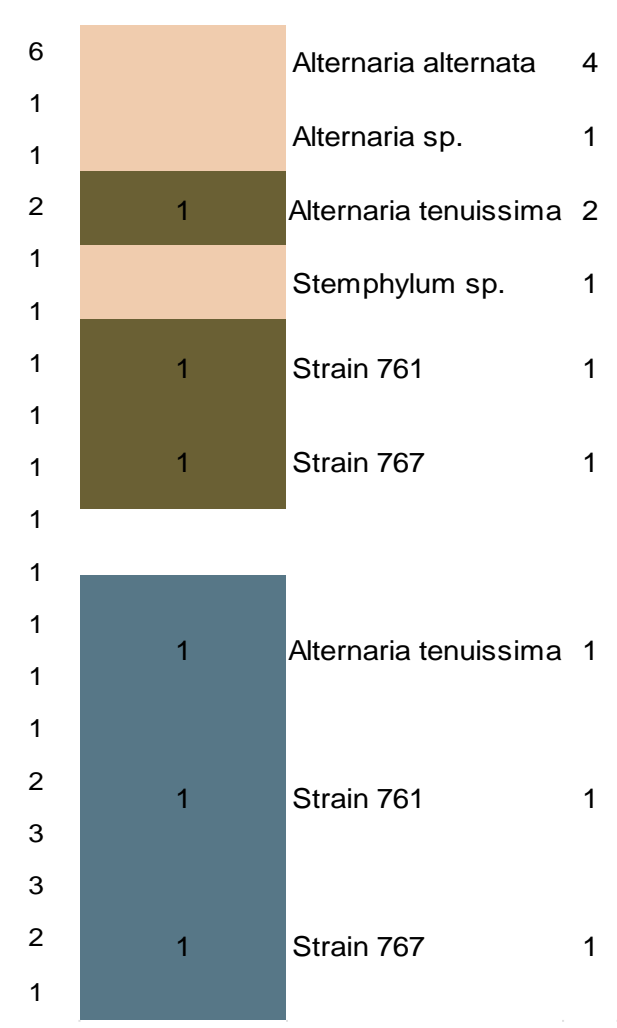

Figure 5. Heatmaps showing the presence (dark colour) or absence (light colour) of symptoms after inoculation of the 76 strains with the different methods (1-5). Numbers on the right of each species correspond to the number of total tested strains, and those on the left represent the number of strains that have produced symptoms. 
The only two isolated strains of Alternaria tenuissima also showed a constant pathogenic ability along the screening sequence. However, in the screening with adult plants (method 4), only one strain of A. tenuissima caused symptoms and was selected for the nursery experiment with other two unidentified strains (761 and 767).

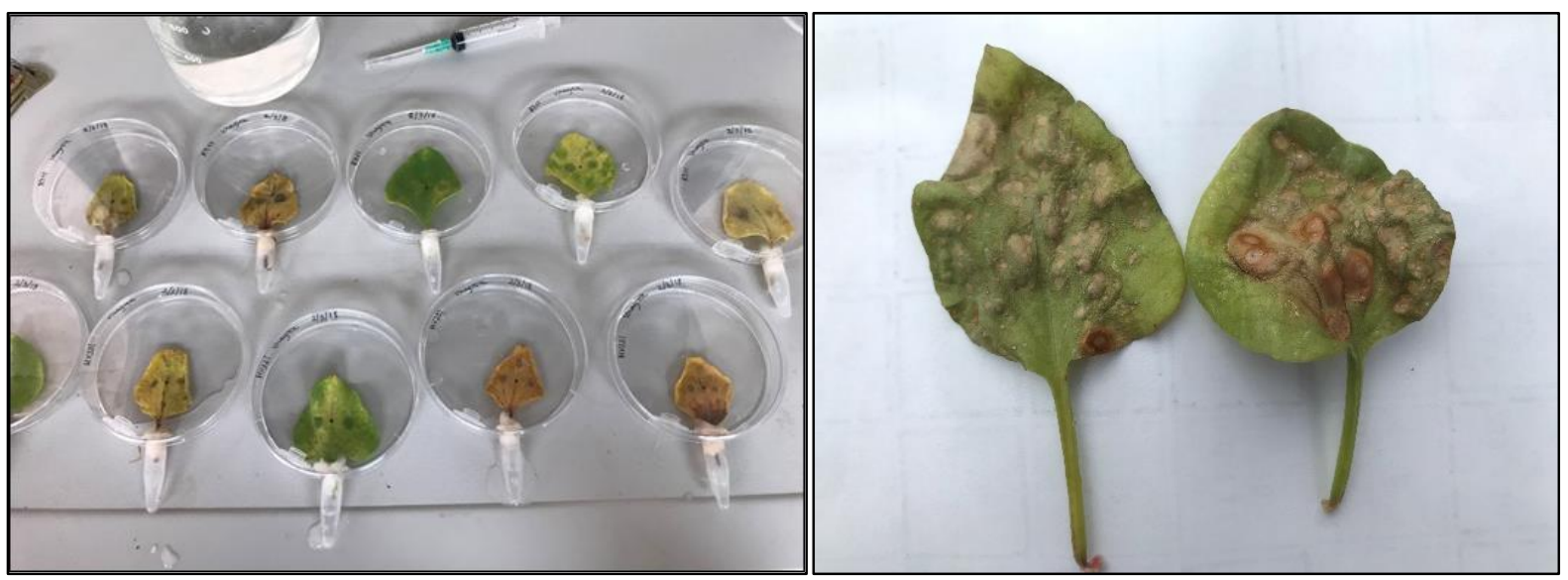

Figure 6. Symptoms produced by the strains tested in method 1 (left) and detail of the leaf spots caused by Alternaria tenuissima (strain 739) in method 5 (right).

In the nursery experiment (method 5), A. tenuissima (strain 739) caused leaf spots of medium size three days after inoculation, while the spots size of the other two strains (761 and 767) was significantly lower (around 16-fold) with similar values in between $(\mathrm{p}<0.05)$ (Figure 7). Yet, six days after inoculation, the leaf spot size caused by all three strains increased and stayed constant until the end of the experiment (nine days). Still, there was a significant higher leaf spot size (around 3.5-fold) caused by A. tenuissima compared to strains 761 and 767 .

Our results indicate that $A$. tenuissima (strain 739) has the fastest and highest pathogenic ability among the strains in this study. Thus, converting it into a potential biocontrol agent for the invasive plant species $R$. lunaria in Lanzarote Island.

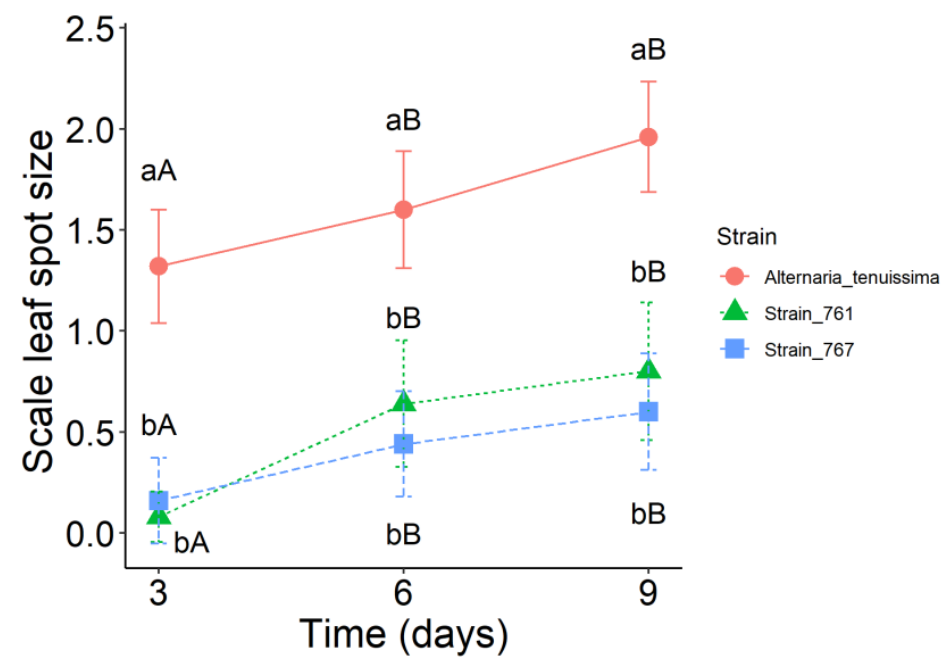

Figure 7. Effect of the three isolated strains on leaf spot size (expressed as a scale 0-3) of Rumex lunaria along the time. Mean values $\pm \mathrm{SE}$ are shown $(\mathrm{n}=5)$. Distinct lower-case letters indicate significant difference among strains, while capital letters indicate significance difference along the time within each single strain (Tukey post-hoc test $\mathrm{p}<0.05$ ). 


\section{Alternaria tenuissima: a potential biological control agent for Rumex lunaria}

Fungal species belonging to Alternaria are mainly saprophytic fungi. However, multiple species have developed pathogenic capacity causing disease on a variety of plants (IacomiVasilescu et al., 2004; Thomma, 2003; Troncoso-Rojas \& Tiznado-Hernández, 2014). The Alternaria species isolated from $R$. lunaria (species complex A. sect. Alternaria, A. tenuissima, A. solani and A. infectoria) are known for its pathogenic character (Meena et al., 2017; MuimbaKankolongo, 2018,; Thomma, 2003). Alternaria fungi attack leaves causing a slow destruction of the tissues by decreasing the photosynthetic potential and leading to necrotic lesions where the fungus colonizes surrounded by a chlorotic halo (Thomma, 2003). Alternaria strains are also used as biological control for different plant species (Babu et al., 2003; Masangkay et al., 1999). In the case of Rumex, species from this genus are also attacked by different strains of Alternaria spp. worldwide: $R$. acetosa is attacked by A. tenuissima in India (Bhale, 2012) A. alternata has been found to be a potential bioherbicide against $R$. dentatus in Pakistan (Siddiqui $\&$ Bajwa, 2008) and causes symptoms of disease on $R$. versicarius in India and Pakistan (Sankar et al., 2012; Siddiqui et al., 2009). The mycoherbicidal metabolites of these two strains of Alternaria were also effective on leaf assays with $R$. dentatus (Mohammed \& Badawy, 2020).

The success of a biological control agent depends in a large extent on the ecosystem where this agent has been isolated from. When the search of pathogenic strains takes place in the environment where it would be inoculated the probability of success is higher. This way, the organism holds the mechanisms to adapt better to the conditions where it will act as a biological control agent, with higher options of developing a successful colonization and act as a pathogen of the target population. In our study, fungal strains were isolated from plants showing symptoms of disease in Lanzarote Island, three of the strains being able to form leaf spots on adult plants in a nursery.

\section{CONCLUSIONS}

Selecting suitable screening methods is fundamental not only to be successful in the search for a potential biological agent, but also to be able to carry out the research from a costeffective economical and logistic perspective. The screening methods we have applied in this study are affordable for any type of laboratory, as they do require neither expensive equipment nor long preparation time. They also allow for the test of the phytopathogenic ability of a high number of strains. There is a trade-off along the sequence of methods between time-and resource efforts and strain testing capacity. In this study, we have proven the ability of three fungal strains (strain 761, strain 767 and Alternaria tenuissima) of producing symptoms (leaf spots) on adult plants under nursery conditions. A. tenuissima showed the fastest and highest colonization capacity. Thus, it constitutes a promising potential biological control agent for the invasive species Rumex lunaria in Lanzarote Island. This is the first step on the long way to search for an effective biological control agent of this species. Confirmation of results in nursery experiments, with a higher number of replicates, scaling to field conditions, mass production and studies about the mechanism of attack of this pathogen and plant defence mechanisms, are needed to successfully define this strain as biological control agent. In parallel, studies of $R$. lunaria population dynamics should be done to define the moment and state of highest weakness of the plant individuals, to better plan the attack strategy. These findings can lead to important management guidelines for the control of this invasive plant that threatens ecosystems in Lanzarote Island and the unique and fragile landscape of Timanfaya National Park. 


\section{ACKNOWLEDGEMENTS}

This study is part of the project "Nuevas actuaciones para el control de la calcosa (Rumex lunaria)" funded by CACT (Centros de Arte, Cultura y Turismo de Lanzarote). The authors would like to thank Cabildo de Lanzarote, Parque Nacional de Timanfaya, Andreea Cosoveanu (ULL) and Gabinete de Estudios Ambientales (Tenerife) for their commitment in the progress of the project.

\section{REFERENCES}

ABDESSEMED, N., BAHET, Y. A., ZERMANE, N. (2020). Mycoherbicide potential of Alternaria alternata (Fries.) Kiessler and its formulations on the host weed Xanthium strumarium L. Biocontrol Science and Technology, 30, 12, 1300-1315. Doi: 10.1080/09583157.2020.1814692.

AGENCIA ESTATAL DE METEOROLOGÍA (AEMET). www.aemet.es

AGENCIA ESTATAL DE METEOROLOGÍA (ESPAÑA) INSTITUTO DE METEOROLOGÍA (PORTUGAL) (2012). Atlas climático de los archipiélagos de Canarias, Madeira y Azores. Agencia Estatal de Meteorología. Doi: 10.31978/281-12-006-X.

ANTEPROYECTO DE LEY DE BIODIVERSIDAD Y DE LOS RECURSOS NATURALES DE CANARIAS, 1 de diciembre de 2021. www.gobiernodecanarias.org

ARECHAVAlETA HERNÁNDEZ, M., Rodríguez, S., Zurita, N. \& García, A. (coord.) (2010). Lista de especies silvestres de Canarias hongos, plantas y animales terrestres, 2009. Gobierno de Canarias.579.

ARÉVALO, J. R., FERNÁNDEZ-LUGO, S., MELlADO, M., DE LA CONCEPCIÓN, T. (2015). Experimental management control of Opuntia dillenii Haw. and Agave americana L. in Teno Rural Park, Canary Islands: Opuntia dillenii and Agave americana Control. Plant Species Biology, 30, 2, 137 146. Doi: 10.1111/1442-1984.12049.

BABU, R. M., SAJEENA, A., SEETHARAM, K. (2003). Bioassay of the potentiality of Alternaria alternata (Fr.) keissler as a bioherbicide to control waterhyacinth and other aquatic weeds. Crop Protection, 22, 8, 1005-1013. Doi: 10.1016/S0261-2194(03)00115-7.

BATES, D., MÄCHLER, M., BOLKER, B., WALKER, S. (2015). Fitting Linear Mixed-Effects Models Using lme4. Journal of Statistical Software, 67, 1-48. Doi: 10.18637/jss.v067.i01

BHALE, U. (2012). First report of Alternaria tenuissima inciting leaf spot of sorrel Rumex acetosa ( L.) In maharashtra, india. Indian Journal of Science Resesearch, 3, 187-188.

BUNN, R. A., RAMSEY, P. W., LEKBERG, Y. (2015). Do native and invasive plants differ in their interactions with arbuscular mycorrhizal fungi? A meta-analysis. Journal of Ecology, 103, 6, 1547-1556. Doi: 10.1111/1365-2745.12456.

CAPDEVILA ARGÜELLES, L., IGLESIAS GARCÍA, A. F. ORUETA, JF (2006). Especies exóticas invasoras: diagnóstico y bases para la prevención y el manejo. Ed. Ministerio De Medio Ambiente: Naturaleza y Parques Nacionales. Madrid: 287.

CHEN, L., ZHOU, J., ZENG, T., MIAO, Y.-F., MEI, L., YAO, G.-B., FANG, K., DONG, X.-F., SHA, T., YANG, M.-Z., LI, T., ZHAO, Z.-W., ZHANG, H.-B. (2020). Quantifying the sharing of foliar fungal pathogens by the invasive plant Ageratina adenophora and its neighbours. New Phytologist, 227, 5, 1493-1504. Doi: 10.1111/nph.16624.

CIRULli, M., COLELLA, C., D'AMICO, M., AMENDUNI, M., BUBICI, G. (2008). Comparison of screening methods for the evaluation of olive resistance to Verticillium dahliae Kleb. Plant Pathology Journal, 90, 7-14.

COATS, V. C., RUMPHO, M. E. (2014). The rhizosphere microbiota of plant invaders: An overview of recent advances in the microbiomics of invasive plants. Frontiers in Microbiology, 5. https://www.frontiersin.org/article/10.3389/fmicb.2014.00368.

COSOVEANU, A., RODRÍGUEZ SABINA, S., GUERRA, G., CABRERA, R., JABAR, A. (2018). Endophytic fungi from Artemisia spp. - enemies of Sclerotinia sclerotiorum. Protectia Plantelor in Agricultura Conventionala si ecologica, 175-179. CZU: 633.88:57.08 
DEL ARCO AGUILAR, M., WILDPRET, W., PAZ, P., DELGADO, O., ACEBES, J., GALlO, A., OSORIO, V. E., REYES-BETANCORT, J., SALAS PASCUAL, M., GONZÁLEZ-GONZÁLEZ, R. (2019). Del Arco et al. 2006 (rev. 2017). Mapa de Vegetación de Canarias.

DUEÑAS, M.-A., HEMMING, D. J., ROBERTS, A., DIAZ-SOLTERO, H. (2021). The threat of invasive species to IUCN-listed critically endangered species: A systematic review. Global Ecology and Conservation, 26, e01476. Doi: 10.1016/j.gecco.2021.e01476

FANG, K., MIAO, Y.-F., CHEN, L., ZHOU, J., YANG, Z.-P., DONG, X.-F., ZHANG, H.-B. (2019). Tissue-Specific and Geographical Variation in Endophytic Fungi of Ageratina adenophora and Fungal Associations with the Environment. Frontiers in Microbiology, 10. https://www.frontiersin.org/article/10.3389/fmicb.2019.02919

GARCÍA, M. I. DE H. (2010). Especies exóticas de flora en la red natura 2000 de España: Propuesta metodológica de actuación. Proceedings from the 14th International Congress on Project Management and Engineering. Comunicaciones presentadas al XIV Congreso Internacional de Ingeniería de Proyectos: 1st Latin American Conference on Project Engineering: Madrid 30 de junio, 1 y 2 de julio de 2010, 2010, ISBN 9788461426072, 154. https://dialnet.unirioja.es/servlet/articulo?codigo=8212406 GARG, H., SIVASITHAMPARAM, K., BANGA, S. S., BARBETTI, M. J. (2008). Cotyledon assay as a rapid and reliable method of screening for resistance against Sclerotinia sclerotiorum in Brassica napus genotypes. Australasian Plant Pathology, 37, 2, 106. Doi: 10.1071/AP08002

GOBIERNO DE CANARIAS (2011). Guía sobre técnicas de producción de especies de interés forestal. Dirección General de Protección de la Naturaleza.

GRIGORESCU, I., KUCSICSA, G., DUMITRAŞCU, M., DOROFTEI, M. (2020). Invasive terrestrial plant species in the Romanian protected areas. A review of the geographical aspects. Folia Oecologica, 47, 2, 168-177. Doi: 10.2478/foecol-2020-0020

IACOMI-VASILESCU, B., AVENOT, H., BATAILLÉ-SIMONEAU, N., LAURENT, E., GUÉNARD, M., SIMONEAU, P. (2004). In vitro fungicide sensitivity of Alternaria species pathogenic to crucifers and identification of Alternaria brassicicola field isolates highly resistant to both dicarboximides and phenylpyrroles. Crop Protection, 23, 6, 481-488. Doi: 10.1016/j.cropro.2003.10.003

INMAN, R. E. (1971). A Preliminary Evaluation of Rumex Rust as a Biological Control Agent for Curly Dock. Phytopathology, 61, 1, 102. Doi: 10.1094/Phyto-61-102

LENTH, R.V. (2021). emmeans: Estimated Marginal Means, aka Least-Squares Means. R package version 1.7.0. https://CRAN.R-project.org/package=emmeans

LIU, G., KENNEDY, R., GREENSHIELDS, D. L., PENG, G., FORSEILLE, L., SELVARAJ, G., WEI, Y. (2007). Detached and Attached Arabidopsis Leaf Assays Reveal Distinctive Defense Responses Against Hemibiotrophic Colletotrichum spp. Molecular Plant-Microbe Interactions ${ }^{\circledR}, 20,10$, 13081319. Doi: 10.1094/MPMI-20-10-1308

MALACRINÒ, A., SADOWSKI, V. A., MARTIN, T. K., CAVICHIOLLI DE OLIVEIRA, N., BRACKETT, I. J., FELLER, J. D., HARRIS, K. J., COMBITA HEREDIA, O., VESCIO, R., BENNETT, A. E. (2020). Biological invasions alter environmental microbiomes: A meta-analysis. PLOS ONE, 15, 10, e0240996. Doi: 10.1371/journal.pone.0240996

MASANGKAY, R. F., PAUlitZ, T. C., HALlETT, S. G., WATSON, A. K. (1999). Factors Influencing Biological Control of Sphenoclea zeylanica with Alternaria alternata f. Sp. Sphenocleae. Plant Disease, 83, 11, 1019-1024. Doi: 10.1094/PDIS.1999.83.11.1019

MEENA, M., GUPTA, S. K., SWAPNIL, P., ZEHRA, A., DUBEY, M. K., UPADHYAY, R. S. (2017). Alternaria Toxins: Potential Virulence Factors and Genes Related to Pathogenesis. Frontiers in Microbiology, 8, 1451. Doi: 10.3389/fmicb.2017.01451

MÉNDEZ, P., ALBAREZ, S. (2014). La Vinagrera. AGROPALCA Publicación Trimestral de la Plataforma Agraria Libre de Canarias, $N^{o} 26$ Julio-Septiembre 2014, 40.

MOHAMMED, Y. M. M., BADAWY, M. E. I. (2020). Potential of phytopathogenic fungal isolates as a biocontrol agent against some weeds. Egyptian Journal of Biological Pest Control, 30, 1, 92. Doi: 10.1186/s41938-020-00295-0

MUIMBA-KANKOLONGO, A. (2018). Vegetable Production. In Food Crop Production by Smallholder Farmers in Southern Africa, 205-274. Doi: 10.1016/b978-0-12-814383-4.00011-6 
ORŁOWSKA, E., LLORENTE, B., OCCITANIC, C. (2013). Plant integrity: An important factor in plant-pathogen interactions. Plant Signaling Behavior, 8,1, e22513. Doi: 10.4161/psb.22513

PACANOSKI, Z. (2015). Bioherbicides. In A. Price, J. Kelton, L. Sarunaite (Eds.), Herbicides, Physiology of Action, and Safety. 253-274. Doi: 10.5772/61528

PAREDES, GIL, R., RODRÍGUEZ, C.G.R., COELlO, R.M. (2018). Programa de control y erradicación de vinagreras. Parque nacional de timanfaya. 42.

PRATT, R. (1996). Screening for resistance to Sclerotinia trifoliorum in alfalfa by inoculation of excised leaf tissue. Doi: 10.1094/PHYTO-86-923

R Core Team (2020). R: A language and environment for statistical computing. R Foundation for Statistical Computing, Vienna, Austria. URL https://www.R-project.org

REN, R., YANG, X., RAY, R.V. (2015). Comparative aggressiveness of Microdochium nivale and M. majus and evaluation of screening methods for Fusarium seedling blight resistance in wheat cultivars.

European Journal of Plant Pathology, 141, 2, 281-294. Doi: 10.1007/s10658-014-0541-3

SANKAR, N.R., DEVAMMA, M.N., GIRIDHAR, D. (2012). First report of Alternaria alternata causing leaf spot on Rumex vesicarius in India. Australasian Plant Disease Notes, 7, 1, 17-18. Doi: 10.1007/s13314-011-0036-4

SIDDIQUI, I., BAJWA, R. (2008). Mass Production of Alternaria alternata Isolates as Potential Bioherbicide Agents for Rumex dentatus and Chenopodium album. International Journal of Agriculture and Biology, 10,6, 722-724.

SIDDIQUI, I., BAJWA, R., JAVAID, A. (2009). First Report of Alternaria alternata Causing Leaf Spot on Rumex dentatus in Pakistan. Plant Disease, 93,4, 431-431. Doi: 10.1094/PDIS-93-4-0431C

THOMMA, B. P. H. J. (2003). Alternaria spp.: From general saprophyte to specific parasite: Alternaria. Molecular Plant Pathology, 4,4, 225-236. Doi: 10.1046/j.1364-3703.2003.00173.x

TRONCOSO-ROJAS, R., TIZNADO-HERNÁNDEZ, M. E. (2014). Alternaria alternata (Black Rot, Black Spot). In Postharvest Decay, 147-187. Doi: 10.1016/B978-0-12-411552-1.00005-3

Vilà, M., Valladares, F., Traveset, A., Santamaría, L., Castro, P. (Ed.) (2008). Invasiones biológicas. Colección Divulgación. Consejo Superior de Investigaciones Cientificas/: Madrid, 215.

WEARN, J.A., SUTTON, B.C., MORLEY, N.J., GANGE, A.C. (2012). Species and organ specificity of fungal endophytes in herbaceous grassland plants: Species and organ specificity of fungal endophytes. Journal of Ecology, 100, 5, 1085-1092. Doi: 10.1111/j.1365-2745.2012.01997.x

WHITE, T., BRUNS, T., LEE, S., TAYLOR, J., INNIS, M., GELFAND, D., SNINSKY, J. (1990). Amplification and Direct Sequencing of Fungal Ribosomal RNA Genes for Phylogenetics. In Pcr Protocols: A Guide to Methods and Applications, 31, 315-322.

WILDPRET, W., BELTRÁN TEJERA, E., GONZÁLEZ-MANCEBO, J.M., CENTELLAS BODAS, A. (1995). Pelargonium capitatum y Rumex lunaria, dos plantas invasoras en el Parque Nacional de Timanfaya (Lanzarote, Islas Canarias). Consideraciones ecológicas y fitosociológicas. In: Estudios Canarios. Anuario del Instituto de Estudios Canarios, 39, 9-16. 